О. О. Чорна

\title{
ОСОБЛИВОСТІ ФУНКЦІОНУВАННЯ МЕТАФОРИ В ПОЛІТИЧНОМУ ДИСКУРСІ СУЧАСНОЇ ПУБЛІЦИСТИКИ (НА МАТЕРІАЛІ УКРАЇНСЬКОЇ ТА ЧЕСЬКОЇ ПЕРІОДИКИ)
}

Чорна О. О. Особливості функціонування метафори в політичному дискурсі сучасної публіцистики (на матеріалі української та чеської періодики).

У статті здійснено спробу порівняльного аналізу метафори в політичному дискурсі 3 позиції особливостей її використання в сучасній українській та чеській публіцистиці.

Ключові слова: метафора, політична метафора, публіцистика, публіцистична метафора.

Черная Е. А. Особенности функционирования метафоры в политическом дискурсе современной публицистики (на материале украинской и чешской периодики).

В статье предпринята попытка сравнительного анализа метафоры в политическом дискурсе с точки зрения особенностей ее употребления в современной украинской и чешской публицистике.

Ключевые слова: метафора, политическая метафора, публицистика, публицистическая метафора.

Chorna O. O. The peculiarities of usage of metaphors in political diskurse of modern social and political journalism (based on Ukrainian and Czech periodicals).

In the annotated article the author makes an attempt to compare metaphors in political diskurse from the point of the peculiarities of its usage in modern Ukrainian and Czech social and political journalism.

Key words: metaphor, political metaphor, social and political journalism, publicistic metaphor.

На сучасному етапі розвитку української та чеської мов політичний дискурс стає важливим чинником як суспільного, так і культурного життя. Політична комунікація відіграє вирішальну роль у процесах розбудови держави, в утвердженні іiі місця у світовому інформаційному просторі. Політична лексика, яка виступає основною складовою політичного мовлення, є одним 3 найбільш рухливих прошарків лексичної системи. 3 одного боку, політична лексика дає змогу дослідити вплив екстралінгвістичних факторів на структуру мови, з іншого, - відіграє найважливішу роль у 
поширенні суспільно-політичних концепцій та формуванні соціальної свідомості населення.

У сучасному інформаційному суспільстві провідну роль відіграє масова комунікація, системи якої формуються під впливом суспільного розвитку, однак значно більший вплив справляють вони самі, значною мірою визначаючи політичні, правові й етичні норми. На сьогодні метафора активно використовується в сучасній українській та чеській публіцистиці, хоча (на відміну від художнього мовлення) саме в публіцистиці особливості метафоричної системи залишаються недостатньо вивченими. Це зумовлює мету даного дослідження - дослідити в порівняльному аспекті особливості використання політичних метафор у сучасній українській та чеській публіцистиці. У нашому дослідженні на матеріалі наймасовіших українських та чеських періодичних видань першого десятиліття XXI ст. загальним обсягом 500000 знаків у кожній мові здійснено спробу аналізу політичної метафори на сучасному етапі іï функціонування в публіцистиці.

Метафора була об’єктом дослідження багатьох мовознавців (Дж. Лакофф, А. Баранов, Ю. Караулов, А. Чудинов, Н. Арутюнова, В. Вовк, Х. Дацишин, Й. Бартошек та ін.). У ширшому розумінні метафора $є$ синонімом тропа, у вужчому - одним із тропів, вмотивованим суто подібністю чи аналогією [2; 6]. Особливо продуктивними семантичними процессами в українській та чеській мовах протягом останніх двох десятиліть є зміни в семантиці слова на основі метафори. Під метафорою розуміємо семантичний процес, при якому форма мовної одиниці переноситься 3 одного об'єкта позначення на інший на основі певної подібності між цими об'єктами при відображенні в свідомості мовця. Механізм метафоричного перенесення значення часто грунтується на основі подібності ознак, властивостей об'єктів номінації. Метафорою в політичному дискурсі публіцистики будемо вважати певний механізм мови, що виявляється у вживанні слова на позначення певного класу предметів, явищ тощо, для характеристики або найменування іншого класу об'єктів на основі певної анології. У розширеному розумінні термін «метафора» можна застосувати до будь-якого вживання слів у непрямому значенні.

Сучасне політичне життя в Україні та Чехії актуалізувало значення політичного слова. Це істотно змінює систему вимог до політика, до кожного члена суспільства та ситуації загалом. Політичні ідеї та владні відносини фіксуються в мові. Тому політичний дискурс задає можливі форми політичної практики. Засоби масової інформації - той соціальний інститут, у якому реалізується політичний дискурс. У вимірах «рівня демократичності» суспільства засоби масової інформації $є$ насправді головним показником, критерієм або певним масштабом. Саме 3МI, по суті, найбільш повно втілюють у собі головну ознаку демократично організованого суспільства.

Якщо говорити про сутність того, що називають сьогодні засобами 
масової інформації, то вже з самої назви можна зрозуміти, що йдеться про інформаційні засоби, які виконують функцію посередників людського спілкування - тобто медіаторів - у сучасному суспільстві. Одна 3 головних, якщо не найголовніша, функція політичного дискурсу 3МI уплив на тих, кому він адресований. За допомогою політичної комунікації різні факти, політичні події, взагалі соціальна реальність інтерпретуються у вигідному для авторів повідомлення світлі, нав'язуючи загалу потрібне розуміння і дії, що з них випливають.

Метафоричність набула статусу важливої ознаки політичного дискурсу й України, і Чехії, що призвело до необхідності осмислення особливого виду метафоричної одиниці - політичної метафори. Останнім часом політична метафора привертає увагу багатьох дослідників (М. Зиміна, А. Баранов, Ю. Караулов, А. Чудинов, Х. Дацишин, І. Кобозева та ін.). Дослідження динаміки моделей політичної метафори - один 3 напрямів когнітивної лінгвістики, що потужно розвивається. Сучасна когнітивістика розглядає метафору як спосіб пізнання, структування та оцінки світу. Використовуючи метафори, людина прагне в процесі комунікації змінити існуючу у свідомості адресата мовну картину світу [18]. У когнітивістиці метафора трактується як основна ментальна операція, що об'єднує дві поняттєві сфери, як засіб пізнання, структурування і пояснення світу. Дискурсивний підхід до вивчення політичної метафоризації передбачає дослідження кожного конкретного тексту з урахуванням політичної ситуації, у якій він створювався, та його співвідношення з іншими текстами [14].

На сьогодні можна виділити два аспекти метафоричної категоризації в політичному мовленні публіцистики. Перший пов'язаний із необхідністю вербальної категоризації нових понять, його наслідком є концептуальна метафора. Політичні медіатексти стають сферою метафоричної деривації найменувань. 3-поміж концептуальних метафор можемо назвати ті, що позначають сталі суспільно-політичні реалії (гілки влади, податковий прес, архітектура безпеки, хвиля страйків, výsoká politika, kontext politiky, scénár reformy); сюди ж можна віднести словосполучення із сигніфікатами метафоричного компонента механізм та важіль (механізм реформ, важелі впливу, cenový mechanizmus). Концептуальні метафори в суспільно-політичній сфері можуть набувати значення термінів. Другий аспект - нова категоризація реальності, пов'язана із вторинною номінацією фрагментів дійсності. Це явище охоплює весь спектр політичних реалій [7].

Аналіз різноманітних контекстів використання метафори свідчить про те, що вона відіграє роль як конструктивного, так і деструктивного компонента дискурсу. Проаналізовані тексти дають підстави вважати, що метафоричний вислів передає більше інформації порівняно з буквальним i водночас акцентує на найсуттєвіших, 3 погляду суб'єкта мовлення, ознаках реалії. Оцінюючи роль метафори як засобу акцентації, можемо 
припустити, що ЗМІ свідомо привертають увагу насамперед до негативних явищ і процесів у політичному житті. Метафора дає змогу певним чином передбачити розвиток політичних подій, наштовхнути читача на потрібну думку; такий спосіб «доопрацювання» інформації $є$ особливо ефективним, бо читач доходить висновку самостійно.

Проведений у дослідженні аналіз політичних метафор у сучасній українській та чеській публіцистиці засвідчив високий рівень метафоризації досліджуваних текстів та різноплановість метафор (від кулінарної до військової): Проте, рецепти антиінфляційної політики стали однією з найбільш популярних «страв» політичної «кухні» (День, 03.06.2008); Говорячи ж про можливі дострокові вибори, вона наголосила, щзо вони «роз'єднають політичні сили», бо «відбувається політичне протистояння, політична війна, боротьба за кожсен відсоток» (Експрес, 20.10.2008); Багато людей розуміють, щуо цүі вибори насправді ніяк не пов'язані з їх об'єктивними інтересами, із завданнями розвитку країни, це не їх конфлікт, це - війна політиків, але в той же час вони готові взяти участь у черговій серії нашої політичної мильної опери (День, 17.08.2007); Zatímсо v parlamentnich volbách voliči ve všech suburbánních obcích př́slušné metropole vybírají ze stejných kandidátních listin, "politické menu» v komunálních volbách je lokální (Dnes, 08.02.2005); Skončí politické války o nasazení českých vojáků v misích (Dnes, 1.12.2009); Necelé dva měsíce před volbou nového prezidenta mění Občanská demokratická strana taktiku, jak dostat svého zakladatele Václava Klause na Hrad (Dnes, 26.11.2002); Posledni volné místopředsednické křeslo po tvrdém boji obsadil ministr pro místní rozvoj Petr Lachnit, který porazil ministra Pavla Mertlika a Jana Kavana (Dnes, 08.02.2001).

Метафора персоніфікації є досить поширеною як в українській, так і в чеській публіцистиці, хоч в українській періодиці персоніфікація все ж трапляється частіше. «Політична реалія - організм» $є$ найпродуктивнішої в україномовному газетному політичному дискурсі України: Держсава ще не була відкритим гравцем на ринковому полі ЗМІ. Вона повинна забрати те, щуо належсть саме держсавним установам, $і$ грати поруч з приватними телеструктурами (День, 21.03.2000); Влада зараз жниве за законами торгівлі-ие найстрашніше! (День, 03.02.2001); Педагоги погоджуються зі свойми вихованцями, щуо держкава недостатньо приділяє уваги обдарованій молоді (Експрес, 08.07.2008); Якщуо ж влада не дослухається до вимог, медики обіияють встановити намети й розиирити масштаби акції (Експрес, 05.11.2005); Політична Україна, налякана привнесеними ззовні технологіями останньої президентської компанії з поділом Украӥни на три сорти та на два береги, занурила голову в пісок і вважає за доречне, жсити в глибинах збаналізованої космополітичної байдужссті, викресливии поняття «нації» з циоденного мовлення (Експрес, 22.08.2007); Держнава не повинна «залазити до кишені студента $і$ пенсіонера» (Експрес, 
25.03.2008); Якщуо держава не хоче помічати мовні проблеми, то, відповідно до Європейської хартії регіональних мов, изе візьмуть на себе органи місиевої влади (Експрес, 28.04.2006); Vláda nemüže nahrazovat neschopnost či neochotu stran vzájemně spolupracovat (Lidové noviny, 14.12.2009); Stát ustoupil zemédělcům, i preses nedostatek peněz jim na dotace přispěje (Lidové noviny, 21.08.2009); Spojené státy podle něj chtějí nastolit nový tón v zahraniční politice a hodlaji klást dưraz na diplomacii, ale nebudou nikomu uznávat sféru vlivu (Lidové noviny, 07.02.2009).

3 наведених вище прикладів видно, що метафора набула достатньо широкого поширення в сучасній публіцистиці. За допомогою метафори тексти періодичних видань стають більш виразними, емоційними. Читач отримує більш повну інформацію про події, що відбуваються в усьому світі. Політична сфера, здавалося, повинна бути бідною на метафори, але на прикладі доної роботи ми переконалися, що це далеко не так.

Уведення в політичний контекст номінацій 3 інших сфер може зумовити піднесене, урочисте звучання, що підкреслює важливість політичної події, особи, явища. Навпаки, іронічне забарвлення вислову 3 метафоричним компонентом найчастіше знецінює політичну подію чи постать. Однією 3 характерних рис сучасної української та чеської публіцистики є метафоризація термінів. Спеціальна термінологія, зокрема вйцськова та спортивна, стає невичерпним джерелом для нових метафор: Але цей удар, по суті, нокаут (вони досі не зрозуміли, думають, щчо ие нокдаун, а насправді че нокаут) - че передача під контроль Свросоюзу газотранспортної системи України (Українська правда, 28.05.2009); Kapitulaci levice před prezidentskými volbami se pokusil zamaskovat sociálnědemokratický předseda Jiři Paroubek velkorysou taktikou, kdy navrhl menším vládním stranám, že bude akceptovat jejich kandidáta (Lidové noviny, 28.02.2009).

Один $з$ найвищих показників метафоризації спостерігаємо власне в прикметника політичний. Цей прикметник стає частиною метафори практично в кожному другому разі в українській публіцистиці, та в кожному третьому - у чеській. В обох мовах такий прикметник трапляється в найрізноманітніших метафоричних конструкціях: політична (-ий) політична атмосфера, політична температура, політична магістраль, політична міна, політичний фініш, політичний сезон, політичні гравиі, політичні ігрища; politická (-ý) - politická scena, politický boj, politická kultura, politická chyba, proti politickým matadori̊m.

Іменникова метафора надає політичній реалії найбільш стійкої характеристики-оцінки. Проаналізовано способи реалізації метафоричного значення іменника: у сполученні з прикметником, який ужито в прямому значенні (виборчий nupiz, politické тепи); через уведення в текст денотата і сигніфіката (громі - це кров економіки). Семантика дієслівної метафори якнайповніше відповідає особливостям політичного дискурсу періодики:

(c) О. О. Чорна, 2013. 
дієслово позначає дію і процес, динамічні ознаки, пов'язані зі змінами властивостей; саме такою динамічною та змінною є сучасна політична реальність (економіка шкутильгає, spravná politika by byla bolestná).

Проаналізованим матеріал дає підстави для певних висновків. Семантичні процеси, зокрема метафоризація суспільно-політичної лексики сучасних української та чеської мов, мають міжнародний контекст i відбуваються за плином класичних процесів у мовних змінах, пов'язаних із соціальним та політичним дискурсом держав. Докорінні політичні зміни в Україні та Чехії кінця XX століття супроводжувались радикальними змінами і в суспільно-політичній свідомості, що вплинуло на систему мови загалом, і на мовні засоби, що вживаються у політичному дискурсі зокрема. Політичний дискурс - це вербалізований вияв політики, мовна дійсність, у конкретних соціальних координатах, соціолінгвістична структура. Сучасний український та чеський політичний дискурс характеризується використанням великої кількості метафор, що засвідчують засоби масової інформації.

Використання метафор зазвичай продиктоване бажанням досягти ефективності друкованого слова, його дієвості, оскільки публіцистика формує суспільну думку. В українській публіцистиці спостерігаємо дещо вищий рівень метафоризації політичної лексики ніж в чеській. Цілеспрямований аналіз метафоричних моделей політичної сфери сприяє виявленню тенденцій розвитку політичного дискурсу та допомагає виявити ступінь впливу соціально-політичних змін на зміни та функціонування політичної мови. Створення метафори здебільшого викликане потребою висловити негативну оцінку, передати негативні емоції, особливо в українській публіцистиці. Метафора - один із найважливіших компонентів політичного дискурсу друкованих 3МI, тісно пов'язаний із його стилістичною та комунікативною спрямованістю. Можна говорити, що в політичному дискурсі функціонує окремий тип метафори - політична, яка лежить на перетині індивідуального світосприйняття та загальноприйнятого, колективного інтерпретування політичних процесів, подій, явищ та особистостей. Активне використання окремих метафоричних моделей супроводжується виникненням штампів, однак воно є закономірним, оскільки відображає зміни в мовній картині світу, фіксує появу нових значень слів. Повторюваність метафор може призвести до створення стереотипізованих уявлень читачів про реалії політичного життя.

\section{Література}

1. Апресян В. Ю. Метафора в семантическом представлении эмоций. Вопросы языкознания / В. Ю. Апресин, Ю. Д. Апресян. - М., 1993. - № 3. - С. 27-35.

2. Арутюнова Н. Д. Метафора и дискурс. Теория метафоры / Н. Д. Арутюнова. - М., 1990.

3. Баранов А. Н. Политическая метафорика публицистического текста : Возможности лингвистического мониторинга. Язык массовой информации как объект междисциплинарного исследования / А. Н. Баранов. - М., 2001. 
4. Вершинина Т. С. Метафора в политическом дискурсе : Традиции и новаторство / Т. С. Вершинина. - Екатеринбург, 2001. - С. 29-32.

5. Володина М. Н. Язык массовой коммуникации - основное средство информационного воздействия на общественное сознание. Язык массовой информации как объект междисциплинарного исследования / М. Н. Володина. - М., 2001.

6. Гак В. Г. Метафора : универсальное и специфическое. Метафора в языке и тексте / В. Г. Гак. - М., 1988. - С. 13.

7. Дацишин X. П. Метафора в українському політичному дискурсі / Х. П. Дацишин. - Львів, 2005. - 260 с.

8. Зимина М. В. Концептуальная метафора в сфере политики // М. В. Зимина / Филологический сборник. - Кемерово, 2002. - Вип. 2.

9. Кобозева И. М. Прагматический подход к идентификации метафоры в политическом дискурсе СМИ. Язык массовой информации как объект междисциплинарного исследования / И. М. Кобозева. - М., 2001. - 477 с.

10. Лакофф Дж. Метафоры, которыми мы живем. Теория метафоры / Дж. Лакофф, М. Джонсон. - Москва, 1990. - 256 с.

11. Москвин В. П. Русская метафора : Параметры классификации / В. П. Москвин // Филологические науки. - М., 2000. - 201 с.

12. Телия В. Н. Метафора и ее роль в создании языковой картины мира. Роль человеческого фактора в языке / В. Н. Телия. - М., 1988. - 333 с.

13. Холявко І. В. Суспільно-політична лексика у пресі 90-х років XX ст. (семантикофункціональний аналіз) : автореф. дис. ... канд. філол. наук : 10.02.01 / І. В. Холявко. Кіровоград, 2004. - 20 с.

14. Чудинов А. П. Российская политическая метафора в начале XXI века / А. П. Чудинов. - Екатеринбург, 2008. - Вип. 1 (24). - С. 86-93.

15. Чудинов А. П. Россия в метафорическом зеркале: Когнитивное исследование политической метафоры (1991-2000) / А. П. Чудинов. - Екатеринбург, 2001. - 238 с.

16. Bartošek J. Jazyk současné české politiky / J. Bartošek. - Olomouc 1993.

17. Daneš F. aj. Český jazyk na přelomu tisíciletí / F. Daneš. - Praha, 1997.

18. Chrz V. Metafory v politice / V. Chrz. - Praha, 1999.

\section{Періодичні видання}

Українські газети «День», «Експрес», «Українська правда» за 2000-2012 рр.

Чеські газети «MF Dnes», «Lidové noviny» за 2000-2012 pp. 